\title{
Development of Critical Thinking Skills: An Analysis of Academic Library Experiences and Other Measures
}

\section{Ethelene Whitmire}

The purpose of this study is to determine the influences that affect the development of critical thinking skills in undergraduate students. This study examines data from the College Student Experiences Questionnaire (CSEQ), a national, cross-sectional survey completed by students during the 1992-1993 academic year. Using Astin's I-E-O model and Pace's quality of effort theory as the conceptual framework, the study examined students' background characteristics, library experiences, experiences with faculty, course learning, and experiences with writing to determine the greatest influences on gains in critical thinking development. Results of the factor analyses and the hierarchical multiple regression indicated that grades, class year, focused academic library activities, informal faculty interaction, active course learning, and conscientious writing all resulted in gains in critical thinking. Implications of these findings suggest that academic librarians should design library research skills courses to increase students' focused use of the academic library and its resources in order to increase their critical thinking skills.

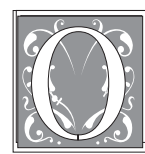

ne of the primary objectives of American higher education is to assist undergraduates in acquiring critical thinking skills. ${ }^{1}$ Higher education studies have examined numerous college experiences to explain undergraduates' development of critical thinking. Based on their review of empirical studies, researchers Ernest T. Pascarella and Patrick T. Terenzini concluded that college attendance has a positive influence on this development. ${ }^{2}$

Critical thinking has been defined as the ability to identify central issues or assumptions in an argument, evaluate conflicting claims, eliminate useless information, evaluate the credibility of an information source, evaluate evidence of authority, provide support for a conclusion, interpret whether conclusions are warranted on the basis of the data given, incorporate anomalous data into a coherent framework, and read with a high level of comprehension. ${ }^{3}$

If it is true, as Pascarella and Terenzini conclude, that college attendance does make a difference in the development of critical thinking skills, we need to determine 
what aspects of the college experience influence this development. Recent higher education studies have identified factors such as student precollege traits, course work and curricular patterns, classroom experiences, out-of-class experiences, student activities, institutional characteristics, and involvement. ${ }^{4}$ These studies also have identified academic library experiences as a factor related to critical thinking development.

According to Barbara MacAdam, critical thinking development "has been the focus of considerable discussion and

\begin{tabular}{|l|l|l|}
\hline \multicolumn{2}{|c|}{$\begin{array}{c}\text { FIGURE 1 } \\
\text { The I-E-O Model }\end{array}$} \\
\hline \hline $\begin{array}{ll}\text { Student } \\
\text { background } \\
\text { characteristics }\end{array}$ & $\begin{array}{l}\text { Environment } \\
\text { Academic } \\
\text { library } \\
\text { experiences }\end{array}$ & $\begin{array}{l}\text { Outcome } \\
\text { Development } \\
\text { of critical } \\
\text { thinking skills }\end{array}$ \\
\cline { 2 - 4 } & $\rightarrow \begin{array}{l}\text { Experiences } \\
\text { with faculty } \\
\text { Course } \\
\text { learning } \\
\text { Experience in } \\
\text { writing }\end{array}$ \\
\hline
\end{tabular}
program development within academic libraries in recent years, primarily as a teaching strategy and as a desired outcome for bibliographic instruction. ${ }^{\prime 5}$ The combination of a new generation of computer-literate undergraduates and the vast amount of information available by way of computers and electronic resources has increased the necessity for the development of critical thinking skills. According to Lizabeth A. Wilson, "students tend to think that everything accessible via computers is useful and accurate. ${ }^{16}$ However, undergraduates need to

\section{Empirical research on academic library experiences and the develop- ment of critical thinking have provided mixed results.}

understand and "be continually reminded that online sources are merely access tools, uncritical purveyors of information. ${ }^{77}$ One of the greatest problems facing librarians today is assisting users in critically evaluating the vast amount of information available to them. ${ }^{8}$

Some librarians have designed programs and services aimed at fostering undergraduates' critical thinking development. Joan Ormondroyd describes four programs at Cornell University in which librarians and faculty work together to develop courses that promote the concept of critical thinking. ${ }^{9}$ Sonia Bodi describes collaborating with faculty to design bibliographic instruction presentations for their courses that will encourage students to develop their critical thinking skills. ${ }^{10}$ In another article, Bodi discusses linking bibliographic instruction with critical thinking by using a scheme of intellectual development as a guide for the goals of the course. ${ }^{11}$ Finally, Eugene A. Engeldinger suggests criteria students should use to evaluate sources when constructing an annotated bibliography. ${ }^{12}$ The criteria are designed to develop critical thinking skills.

\section{Review of the Literature}

Empirical research on academic library experiences and the development of critical thinking have provided mixed results. John C. Ory and Larry A. Braskamp studied the relationship between the quality of effort students put into their involvement in activities and the subsequent impact on student growth and development. ${ }^{13}$ They defined intellectual growth and development with terms representing critical thinking (e.g., ability to think analytically and logically, ability to put 
ideas together, and so on). There were moderate positive correlations between academic activities (library experiences, experiences with faculty, course learning, writing) and gains in critical thinking for students in the honors $(n=74)$ and transitional program $(n=74)$ and low positive correlations between the two factors and with the regular students (n $=77$ ). There were low positive correlations between interpersonal activities (e.g., personal experiences, experiences with peers, etc.) and gains in critical thinking skills for all three groups. The authors used the College Student Experiences Questionnaire (CSEQ), which measures the quality of effort that students engage in developed by C. Robert Pace. ${ }^{14}$ Ory and Braskamp found a strong relationship between library experiences and gains in critical thinking. ${ }^{15}$

Patrick T. Terenzini and others studied the effect of three dimensions of students' college experiences: curricular exposure; formal classroom and instructional experiences; and out-of-class experiences on critical thinking. ${ }^{16}$ They found that formal classroom and instructional experiences and out-of-class experiences on critical thinking contributed to gains in critical thinking. This was a one-year longitudinal, panel study design in which six hundred students were studied at a large, urban research university in the Midwest. The students completed Form 88B of the Collegiate Assessment of Academic Proficiency (CAAP) measuring

in stacks project faculty

\section{TABLE 1}

Descriptive Statistics for the Variables in the Analysis

\begin{tabular}{lcc}
\hline \hline & \multicolumn{3}{c}{$\begin{array}{c}\text { Mean }{ }^{*} \\
\text { Deviation } \\
\text { Dlock 1: Background Characteristics }\end{array}$} \\
\hline Age & $1.31^{\dagger}$ & .64 \\
Gender & $.60^{\ddagger}$ & .49 \\
Race & $.24^{\S}$ & .43 \\
Class & $2.40^{\|}$ & 1.23 \\
Grades & $3.17^{\#}$ & 1.14 \\
Majors & $.50^{* *}$ & .50 \\
& & \\
& Block 2: Academic Library Experiences \\
\hline
\end{tabular}

Used indexes to journal articles

$2.01 \quad .84$

$\begin{array}{lll}\text { Developed bibliography } & 2.30 & .91\end{array}$

$\begin{array}{lll}\text { Used card catalogue or computer } & 2.49 \quad .89\end{array}$

$\begin{array}{lll}\text { Asked librarian for help } & 2.00 \quad .79\end{array}$

$\begin{array}{lll}\text { Read in reserve or reference section } & 1.94 & .81\end{array}$

$\begin{array}{lll}\text { Checked citations in things read } & 1.73 \quad .81\end{array}$

$\begin{array}{lll}\text { Read basic references or documents } & 1.48 & .69\end{array}$

$\begin{array}{lll}\text { Found material by browsing } & 1.78 \quad .85\end{array}$

$\begin{array}{lll}\text { Checked out books } & 1.82 \quad .87\end{array}$

Block 3: Experiences with Faculty

$\begin{array}{lll}\text { Talked with faculty member } & 2.81 & 84\end{array}$

$\begin{array}{lll}\text { Asked for info related to a course } & 2.62 & .83\end{array}$

$\begin{array}{lll}\text { Visited informally after class } & 2.32 \quad .86\end{array}$

$\begin{array}{lll}\text { Made office appointment with faculty } & 2.12 & .81\end{array}$

$\begin{array}{lll}\text { Discussed term paper/project } & 2.08 & .81\end{array}$

with faculty

$\begin{array}{lll}\text { Discussed career plans with faculty } & 1.92 & .84\end{array}$

$\begin{array}{lll}\text { Asked for comments/criticism } & 1.96 \quad .84\end{array}$ about work

Had coffee, cokes, snacks with faculty $1.32 \quad .63$

$\begin{array}{lll}\text { Worked with faculty on research } & 1.21 \quad .56\end{array}$

$\begin{array}{lll}\text { Discussed personal problems with } & 1.40 \quad 67\end{array}$

critical thinking developed by American College Testing in the fall of 1991. During the spring 1992 term, students completed the follow-up Form 88A of CAAP and items from the CSEQ measuring students' in-class and out-of-class experiences in college. The results of the regres- 


\begin{tabular}{|c|}
\hline TABLE 1 (cont.) \\
Descriptive Statistics for the \\
Variables in the Analysis
\end{tabular}

\begin{tabular}{cc} 
Mean & $\begin{array}{c}\text { Standard } \\
\text { Deviation }\end{array}$ \\
\hline
\end{tabular}

Block 4: Course Learning

\begin{tabular}{lll}
\hline Took detailed notes in class & 3.48 & .69 \\
Participated in class discussions & 2.86 & .83 \\
Underlined major points in readings & 2.95 & .93 \\
Saw how facts and ideas fit together & 2.90 & .82 \\
Thought about practical applications & 2.84 & .82 \\
Integrated ideas from various sources & 2.81 & .88 \\
Summarized major points & 2.77 & .87 \\
$\quad$ & \\
$\quad$ and information & & .80 \\
Explained material to another student & 2.77 & .99 \\
Made outlines from notes or readings & 2.27 & .82 \\
$\quad$ & 1.87 & \\
\multicolumn{2}{c}{ Block 5: Experiences with Writing } \\
\hline
\end{tabular}

\begin{tabular}{llr}
\hline Used dictionary or thesaurus & 3.02 & .85 \\
Thought about grammar etc, & 3.12 & .84 \\
$\quad$ while writing & & \\
Wrote rough draft and revised it & 3.16 & .89 \\
Spent 5 or more hours writing a paper & 2.86 & 1.01 \\
Asked others to read something & 2.72 & .97 \\
$\quad$ you wrote & & \\
Referred to style book or grammar & 2.49 & .97 \\
$\quad$ manual & & \\
Revised paper two or more times & 2.51 & 1.01 \\
Asked instructor for advice on writing & 2.12 & .97 \\
Made appointment to talk about & 1.79 & .93 \\
$\quad$ criticism & & \\
Submitted writing for publication & 1.27 & .68 \\
$\quad$ Dependent Variable: Critical Thinking & \\
\hline Gain in ability to put ideas together & 2.78 & .79 \\
Gain in ability to think analytically & 2.71 & .82 \\
Gain in ability to learn on own & 2.92 & .81 \\
Gain in quantitative thinking & 2.37 & .89 \\
\hline
\end{tabular}

* Means are on a scale of 1 to 4 with $1=$ never and $4=$ very often except in Block 1 as noted.

$\dagger \quad 1=22$ or younger to $3=28$ or older

† $1=$ female; $0=$ male

$\S 1=$ minority; $0=$ white

\| $1=$ freshman to $4=$ senior

\# $1=\mathrm{C}$ or lower to $5=\mathrm{A}$

** $0=$ professional; $1=$ liberal arts sion analysis indicated that variables predicting gains in critical thinking included precollege characteristics (parents' education, initial critical thinking ability); out-of-class experiences (relationships with students, number of nonassigned books read); and class-related experiences (hours per week spent studying). No variables describing the types of courses taken (e.g., math, science, or arts and humanities) proved to be significant. However, this study found that library experiences were significantly and negatively related to the development of critical thinking. This negative relationship between academic library experiences and critical thinking development also was found in a similar study by the same authors. ${ }^{17}$

\section{Statement of the Problem}

Considering the mixed results of the previous empirical research examining the relationship between academic library experiences and the development of critical thinking skills, this study uses a different conceptual framework. The research questions for this study are:

1. What factors influence the development of critical thinking skills?

2. What is the role of the academic library experiences of undergraduates in their development of critical thinking?

The conceptual framework for this study is the I-E-O model developed by Alexander W. Astin and the quality of effort theory developed by C. Robert Pace. ${ }^{18,19}$ The I-E-O model represents inputs, environment, 
and outcome. The inputs and the environment represent the independent variables. The inputs in this study are the students' background characteristics. The environment consists of the college experiences (with the academic library, the faculty, writing, and course learning). Finally, the outcome is the dependent variable - the development of critical thinking skills. The quality of effort theory postulates that student outcomes are related to the amount of time and energy students expend on their college experiences (see figure 1).

\section{The Method Section}

\section{Data Source}

This study utilized data obtained from the 1992-1993 CSEQ. The CSEQ was designed to assess the levels of time and effort students invest in their college activities, among other items. The study examined data from six sections of the CSEQ: (1) background information, (2) library experiences, (3) experiences with faculty, (4) course learning, (5) experiences with writing, and (6) estimate of gains in critical thinking (see table 1).

\section{Subjects}

The data set contained 18,157 students attending all institutional types (research universities, doctoral universities, comprehensive colleges and universities, liberal arts colleges, and community colleges). The majority of the students in the sample were traditional-aged college students, female, and white. The average grade for the sample was a B. Finally, the students in the sample were split evenly between professional and liberal arts majors. Although most students in the sample had talked with a faculty member, most had not worked with

\section{TABLE 2 \\ Factor Loadings and Internal Consistencies for Exploratory Factor Model of Library Experiences, Experiences with Faculty, Course Learning, Experiences with Writing, and Critical Thinking Variables}

Factors and Survey Items Factor Loading

Academic Library Reference Activities (internal consisitency $=.77$ )

Used indexes to journal articles $\quad .68$

Developed bibliography $\quad .67$

Used card catalogue or computer $\quad .65$

Asked librarian for help $\quad .49$

Read in reserve or reference section $\quad .44$

Academic Library Probing Activities (internal consisitency $=.75$ )

Checked citations in things read $\quad .66$

Read basic references or documents $\quad .65$

Found material by browsing in stacks $\quad .64$

Checked out books $\quad .52$

Experiences with Faculty-Informal Contacts (internal consisitency $=.89$ )

Asked for info related to a course $\quad .78$

Visited informally after class $\quad .73$

Talked with faculty member $\quad .73$

Made office appointment with faculty $\quad .64$

Discussed term paper/project with faculty $\quad .62$

Asked for comments/criticism about work $\quad .58$

Discussed career plans with faculty $\quad .55$

Experiences with Faculty-Personal,

Social, Work Contacts

(internal consisitency $=.68$ )

Had coffee, cokes, snacks with faculty $\quad .67$

Discussed personal problems with faculty $\quad .62$

Worked with faculty on research project $\quad .50$

Course Learning-Participation and Application (internal consisitency $=.75$ )

Saw how facts and ideas fit together $\quad .76$

Thought about practical applications $\quad .74$

Participated in class discussions $\quad .46$

Integrated ideas from various sources $\quad .45$ 


\begin{tabular}{|c|}
\hline TABLE 2 (cont.) \\
Factor Loadings and Internal Consistencies \\
for Exploratory Factor Model of Library \\
Experiences, Experiences with Faculty, \\
Course Learning, Experiences with Writing, \\
and Critical Thinking Variables \\
\hline \hline
\end{tabular}

Factors and Survey Items

Factor Loading

Course Learning-Integrative Activities (internal consisitency $=.75$ )

Made outlines from notes or readings .72

Summarized major points and information .65

Did additional readings

Explained material to another student

Underlined major points in readings

Experiences with Writing-Basic Mechanisms and Conscientious Revisions

(internal consisitency $=.86$ )

Wrote rough draft and revised it $\quad .76$

Thought about grammar, etc., while writing $\quad .70$

Spent five or more hours writing a paper $\quad .65$

Used dictionary or thesaurus

.63

Revised paper two or more times

.61

Referred to stylebook or grammar manual

.57

Asked others to read something you wrote $\quad .57$

Experiences with Writing-Critical Advice and Quality

(internal consisitency $=.70$ )

Asked instructor for advice on writing $\quad .78$

Made appointment to talk about criticism $\quad .77$

Submitted writing for publication

.36

Critical Thinking

(internal consisitency $=.82$ )

Gain in ability to put ideas together .83

Gain in ability to think analytically

.79

Gain in ability to learn on own

.67

Gain in quantitative thinking demic library experiences, the students in the sample selected the variable "used card catalogue or computer" as the library experience they engaged in most often and "read basic references or documents" as the activity they engaged in less frequently (see table 1).

\section{Analyses}

Exploratory factor analyses were conducted utilizing orthogonal, principal-axis factor rotation methods to reduce the number of measured variables for analyses and to eliminate highly correlated variables. Oblique factor analyses were used in this study based on the assumption that these factors were correlated. Items that had a factor score of at least .35 or over were retained in the development of subsequent scales.

Blocked hierarchical multiple regression was used to determine the amount of influence of each variable and factor on undergraduate development of critical thinking skills. Using Astin's I-EO model, the variables representing the inputs were entered first, followed by the factors representing the environment.

\section{Results}

The factor analyses resulted in two academic library experiences factors. One factor represented library reference activities described by C. Robert Pace as "routine, moderately exploratory use" and library probing activities which refer to "increased amounts

faculty on a research project. Nearly all the students stated that they took detailed notes in class, but few did any additional readings for their courses. The majority of the students wrote rough drafts and revised their papers, but few submitted them for publication. Regarding aca- of independent exploration and focused activity." 20 The experiences with faculty members broke into two factors representing informal and formal contact. The two resulting factors describing course learning represent class participation and integrative activities. Experiences with 


\begin{tabular}{|c|c|c|}
\hline \multicolumn{3}{|c|}{$\begin{array}{c}\text { TABLE } 3 \\
\text { Summary of Regression Analysis for } \\
\text { Variables Predicting Development of } \\
\text { Critical Thinking Skills } \\
\end{array}$} \\
\hline Variable & $\mathrm{B}$ & $\begin{array}{c}\text { Significance } \\
\text { Level }\end{array}$ \\
\hline \multicolumn{3}{|c|}{ Inputs } \\
\hline $\begin{array}{l}\text { Race } \\
\text { Gender } \\
\text { Age } \\
\text { Class } \\
\text { Grades } \\
\text { Major }\end{array}$ & $\begin{array}{r}.11 \\
-.43 \\
-.34 \\
.29 \\
.07 \\
-.07\end{array}$ & $\begin{array}{l}* * * \\
* * * \\
* * * \\
* * *\end{array}$ \\
\hline \multicolumn{3}{|c|}{ Environment } \\
\hline $\begin{array}{l}\text { Academic library } \\
\text { reference activities }\end{array}$ & .01 & \\
\hline $\begin{array}{l}\text { Academic library } \\
\text { probing activities }\end{array}$ & .03 & $* * *$ \\
\hline $\begin{array}{l}\text { Experiences with } \\
\text { faculty_informal } \\
\text { contacts }\end{array}$ & .04 & $* * *$ \\
\hline $\begin{array}{l}\text { Experiences with } \\
\text { faculty—personal, } \\
\text { social, work } \\
\text { contacts }\end{array}$ & .03 & \\
\hline $\begin{array}{l}\text { Course learning- } \\
\text { participation and } \\
\text { application }\end{array}$ & .26 & $* * *$ \\
\hline $\begin{array}{l}\text { Course learning- } \\
\text { integrative activities }\end{array}$ & .09 & $* * *$ \\
\hline $\begin{array}{l}\text { Experiences with } \\
\text { writing_basic } \\
\text { mechanisms }\end{array}$ & .05 & $* * *$ \\
\hline $\begin{array}{l}\text { Experiences with } \\
\text { writing-critical } \\
\text { advice and quality }\end{array}$ & -.00 & \\
\hline $\begin{array}{l}\text { Final } \mathrm{R}^{2}=.21 \\
* * * \mathrm{p}=\sim .001\end{array}$ & & \\
\hline
\end{tabular}

writing also broke into two factors representing using basic mechanisms and conscientious revisions and seeking critical advice. Finally, four variables represent the critical thinking factor. These results are shown in table 2 along with the alpha reliabilities of the factors, which ranged from .68 to .89 .

The results of the blocked hierarchical regression reported in table 3 revealed that women and older students were less likely to report gains in critical thinking. Upperclassmen and students with higher grades were more likely to report gains. Routine use of the academic library did not influence critical thinking development. However, students engaged in more focused library activities reported a significant impact on their critical thinking development. Likewise, students reporting more effort in engaging in informal contact with faculty (including discussing a term paper with faculty), actively participating in course learning, and making conscientious revisions in their writing reported greater gains in their critical thinking.

\section{Conclusions}

Considering the results of the analyses in this study, several factors can increase undergraduate development of critical thinking skills. Faculty and librarians can work together to help students achieve this desirable learning outcome. The results of the regression analysis indicate that students need to meet with their faculty members more often to discuss their term papers among other concerns, become active class participants, work on their writing skills, and use the academic library for more focused activities.

\section{Notes}

1. Alexander W. Astin, Assessment for Excellence: The Philosophy and Practice of Assessment and Evaluation in Higher Education (Phoenix, AZ: Oryx Pr., 1993); Sonia Bodi, "Critical Thinking and Bibliographic Instruction: The Relationship," Journal of Academic Librarianship 14 (1988): 150-53; Diane F. Halpern, "Assessing the Effectiveness of Critical Thinking Instruction," Journal of General Education 42 (1993): 238-54; Ernest T. Pascarella et al, "Is Differential Exposure to College Linked to the Development of Critical Thinking?" Research in Higher Education 37 (1996): 159-74. 
2. Ernest T. Pascarella and Patrick T. Terenzini, How College Affects Students: Findings and Insights from Twenty Years of Research (San Francisco: Jossey-Bass, 1991).

3. C. Furedy and J. Furedy, "Critical Thinking: Toward Research and Dialogue," Using Research to Improve Teaching (New Directions for Teaching and Learning No. 23), eds. J. Donald and A. Sullivan (San Francisco: Jossey-Bass, 1985); Halpern, "Assessing the Effectiveness of Critical Thinking Instruction," 238-54.

4. John C. Ory and Larry A. Braskamp, "Involvement and Growth of Students in Three Academic Programs," Research in Higher Education 28 (1988): 116-29; Patrick T. Terenzini et al, "First-Generation College Students: Characteristics, Experiences, and Cognitive Development," Research in Higher Education 37 (1996): 1-22; __ "Academic and Out-of-Class Influences on Student' Intellectual Orientations," Review of Higher Education 19 (1995): 23-44; —_, "Influences Affecting the Development of Students' Critical Thinking Skills," Research in Higher Education 36 (1995): 23-39.

5. Barbara MacAdam, "Sustaining the Culture of the Book: The Role of Enrichment Reading and Critical Thinking in the Undergraduate Curriculum," in Library Trends, vol. 44, eds. T. G. McFadden and T. J. Hostetler (Champaign, Ill.: Univ. of Illinois Graduate School of Library and Information Science, 1995), 237-63.

6. Lizabeth A. Wilson, "Changing Users: Bibliographic Instruction for Whom?" in The Evolving Educational Mission of the Library, eds. Betsy Baker and Mary Ellen Litzinger (Chicago: ACRL, 1992), 30-31.

7. Sonia Bodi, "Collaborating with Faculty in Teaching Critical Thinking: The Role of Librarians," Research Strategies 10 (1992): 69-76.

8. Keith Morgan, "Information-Seeking Behavior: Challenges for Reference Services," LIBRES: Library and Information Science Research Electronic Journal 3 (1993).

9. Joan Ormondroyd, "The Role of the Library in Promoting Critical Thinking in the Classroom and Beyond," in Russian-American Seminar on Critical Thinking and the Library, vols. 200/ 201 eds. Cerise Oberman and Dennis Kimmage (Champaign, Ill.: Univ. of Illinois Graduate School of Library and Information Science, 1995), 119-25.

10. Bodi, "Collaborating with Faculty in Teaching Critical Thinking," 69-76.

11. _ "Critical Thinking and Bibliographic Instruction: The Relationship," 150-53.

12. Eugene A. Engeldinger, "Bibliographic Instruction and Critical Thinking: The Contribution of the Annotated Bibliography," RQ 28 (1988): 195-202.

13. Ory and Braskamp, "Involvement and Growth of Students in Three Academic Programs," 116-29.

14. C. Robert Pace, Measuring the Quality of College Student Experiences (Los Angeles: Univ. of California Higher Education Research Institute, 1984).

15. Ory and Braskamp, "Involvement and Growth of Students in Three Academic Programs," 116-29.

16. Terenzini et al, "Influences Affecting the Development of Students' Critical Thinking Skills," 23-39.

17. — "Academic and Out-of-Class Influences on Student' Intellectual Orientations," 23-44.

18. Astin, Assessment for Excellence.

19. Pace, Measuring the Quality of College Student Experiences.

20. Ibid. 